\title{
Law and Energy Transitions: Wind Turbines and Planning Law in the UK
}

\author{
Elizabeth Fisher*
}

\begin{abstract}
Through a study of planning law and the legal challenges to wind energy planning decisions, this article shows how law plays an important role in framing understandings of both wind energy projects and decision-making in regards to such projects. Law also provides important forums for dispute resolution. These frames and these forums create legal stability in the wake of the legal disruption created by the introduction of wind energy as a significant energy infrastructure. Highlighting that role raises important questions for scholars of energy transitions, planning law, and social regulation more generally.
\end{abstract}

Keywords: planning law, administrative law, courts, energy transitions

\footnotetext{
* Professor of Environmental Law, Faculty of Law and Corpus Christi College, University of Oxford. Email: liz.fisher@law.ox.ac.uk. I would like to thank Randall Stephenson for his outstanding research assistance and Joanna Bell, Sanja Bogojevic, Mr Justice Ian Dove, and Ceri Warnock for comments on earlier drafts. A version of this paper was presented the 'Regulating the Energy Transition' workshop, All Souls College, Oxford, an Auckland Law School staff seminar, and the European Union Forum of Judges for the Environment Conference 2017. Any omissions or errors are my own.
} 


\section{Introduction}

Wind energy now makes a significant contribution to UK electricity supplies. ${ }^{1}$ This reflects the energy transition that has been taking place over the last two decades in an attempt to mitigate anthropocentric climate change. This transition has been catalysed by a series of legal reforms stretching back to the creation of a Non-Fossil Fuel Obligation in the UK Electricity Act $1989 .{ }^{2}$ Wind energy has also been promoted in a range of national policies. ${ }^{3}$ The production of wind energy requires the building of wind turbines and thus engages planning law. As one planning

\footnotetext{
${ }^{1}$ In the third quarter of $2017,30 \%$ of energy generation came from renewables including $12.8 \%$ through onshore (5.3\%) and offshore (7.5\%) wind turbines. DECC, Energy Trends Section 6:
} Renewables (February 2018) https://www.gov.uk/government/statistics/energy-trendssection-6-renewables accessed 17 February 2018. For a history see Florian Kern, Caroline Kuzemko, and Catherine Mitchell, 'Measuring and Explaining Policy Paradigm Change: The Case of UK Energy Policy' (2014) 42 Policy \& Politics 513.

${ }^{2}$ Section 32, Electricity Act 1989. See also Directive 2009/28/EC of the European Parliament and of the Council of 23 April 2009 on the promotion of the use of energy from renewable sources and amending and subsequently repealing Directives 2001/77/EC and 2003/30/EC [2009] L140/16. For an overview of that history see David Newbery, 'Towards a green energy economy? The EU Energy Union's transition to a low-carbon zero subsidy electricity system - Lessons from the UK's Electricity Market Reform'(2016) 179 Applied Energy 1321.

${ }^{3}$ The Scottish government has been a particularly keen proponent of renewables, Scottish Government, 2020 Routemap for Renewable Energy in Scotland (2011), < http://www.gov.scot/Publications/2011/08/04110353/3> accessed 19 February 2018. 
law practitioner notes 'A wind turbine proposal almost inevitably gives rise to a conflict situation' and in doing so gives rise to legal disputes. ${ }^{4}$ Between 1995 and 2017 in the UK there were 137 judgments concerning legal challenges to decisions concerning planning applications relating to the building of wind turbines.

This state of affairs is not unique to the UK or to wind energy. It can also be seen in relation to other jurisdictions ${ }^{5}$ and other energy transitions. ${ }^{6}$ National governments promote a new energy source, but its implementation leads to conflict, and in particular legal conflict. ${ }^{7}$ Social science scholarship has predominantly framed these disputes as between the global

${ }^{4}$ Alec Samuels, 'Wind Turbine Law: An Overview' [2013] JPEL 1255, 1255. See also Marcus Trinick, 'Green on Green: Planning for Wind Energy’ [2006] JPEL Dec Supp 89, 112.

${ }^{5}$ Derek Bell and others, 'Re-visiting the 'Social Gap': Public Opinion and Relations of Power in the Local Politics of Wind Energy'(2013) Environmental Politics 115 and Patrick DevineWright (ed), Renewable Energy and the Public: From Nimby to Participation (Earthscan 2011).

${ }^{6}$ Frank Geels and others, 'The Enactment of Socio-technical Transition Pathways: A Reformulated Typology and a Comparative Multi-level Analysis of the German and UK LowCarbon Electricity Transitions (1990-2014)'(2016) 40 Research Policy 896 and Andy Stirling, 'Transforming Power: Social Science and the Politics of Energy Choices'(2014) 1 Energy Research and Social Sciences 83.

${ }^{7}$ N Hall, P Ashworth and P Devine Wright, 'Societal Acceptance of Wind Farms: Analysis of Four Common Themes Across Australian Case Studies'(2013) 58 Energy Policy 200. 
commitment to tackling climate change and local interests. ${ }^{8}$ The national/local axis has also become important in government policy. ${ }^{9}$ While there are some notable exceptions, ${ }^{10}$ there has

${ }^{8}$ Michael Ogilvie and Christopher Rootes, 'The Impact of Local Campaigns Against Wind Energy Developments'(2015) 24 Environmental Politics 874; Joyce McLaren Loring, 'Wind Energy Planning in England, Wales and Denmark: Factors Influencing Project Success'(2007) Energy Policy 2648; Lennart Lundqvist and Anders Biel, 'From Kyoto to the Town Hall: Transforming National Strategies into Local and Individual Action' in Lennart Lundqvist and Anders Biel (eds), From Kyoto to the Town Hall: Making International and National Climate Policy Work at the Local Level (Earthscan 2007) 2; Kate Burningham, Julie Barnett and Gordon Walker, 'An Array of Deficits: Unpacking NIMBY Discourses in Wind Energy Developers' Conceptualizations of Their Local Opponents'(2015) 28 Society and Natural Resources 246; Susana Batel and Patrick Devine-Wright, 'A Critical and Empirical Analysis of the National-Local 'Gap' in Public Responses to Large-Scale Energy Infrastructures'(2015) 58 Journal of Environmental Planning and Management 1076.

${ }^{9}$ Department of Communities and Local Government, Planning Practice Guidance: Renewable and Low Carbon Energy, Paragraph: 003 Reference ID: 5-003-20140306 (Revision Date 6 March 2014), http://planningguidance.communities.gov.uk/blog/guidance/renewable-andlow-carbon-energy/developing-a-strategy-for-renewable-and-low-carbon-energy/ accessed 19 February 2018; Climate Change Committee, How Local Authorities Can Reduce Emissions and Manage Climate Risk (May 2012) 9; and Department of Energy and Climate Change, UK Renewable Energy Roadmap (July 2011) 27.

${ }^{10}$ Maria Lee, 'Knowledge and Landscape in Wind Energy Planning'(2017) 37 Legal Studies 3 and Chris Hilson, 'Framing Fracking: Which Frames Are Heard in English Planning and Environmental Policy and Practice?'(2015) 27 Journal of Environmental Law 177. 
been little in-depth analysis of the role of planning law in relation to these types of conflicts. Furthermore, beyond the work of practitioners, there has been little scholarly focus on planning case law.

In this article, I show how planning law, and in particular planning case law, is a significant stabilising force that responds to the disruption caused by the introduction of a new energy infrastructure in two interrelated ways. First, planning law through legislation, delegated legislation, and policy 'frames' what is understood to be an acceptable wind energy project. Those frames have their foundations in the existing legal landscape. Second, legal disputes concerning wind energy projects are not only forums for dispute resolution but also for developing understandings of good decision-making in relation to wind energy projects. Overall, law, legal norms, and legal forums are making law 'calculable'11 and shaping how wind energy is put into operation and how it relates to other commitments in the legal order. This account of law not only challenges many social science and policy accounts of energy transitions, but also how planning law has been characterised by scholars as being a goal-driven and ideological area of the law. ${ }^{12}$

This article is structured as follows. In Section 2, I give a brief overview of the legally disruptive nature of the transition to wind energy and in Section 3 I analyse the planning law frameworks that relate to the building of wind turbines and show how they frame what is understood as an acceptable wind turbine project. In Section 4, an overview is given of the case law relating to decisions concerning planning permissions for wind energy projects and the

${ }^{11}$ Jeremy Waldron, The Rule of Law and the Measure of Property (Cambridge University Press 2012) 53 .

${ }^{12}$ Patrick McAuslan, The Ideologies of Planning Law (Pergamon Press 1980). 
main grounds of legal challenge in these cases. In Section 5, I consider the implications of my analysis.

There are three points to be made before starting. First, this article is not about being for or against wind turbines. It is about how the role of law is understood in contexts such as these. Second, the conclusions here about law are relevant to not only other energy transitions. ${ }^{13}$ and planning law, but also to how similar areas of administrative law are understood. This article is thus part of a larger intellectual project concerned with thinking about the substantive role of law in these areas. ${ }^{14}$ Finally, while the analysis in this article is based on an examination of all the case law concerning challenges to wind turbine planning decisions, the examples provided are illustrative not exhaustive. It also primarily considers legal challenges relating to mainstream planning law processes. It does not, for example,

${ }^{13}$ Given the recent nature of climate change policies, we tend to think of these processes of change happening now or in the future but consider for example the case law that the building of hydroelectric dams has given to across the world. Eg 1983 Commonwealth v Tasmania ("Tasmanian Dam Case") (1983) 158 CLR 1 (constitutional competence issues); Tennessee Valley Authority $v$ Hill 437 US 153 (1978) (endangered species implications); and $R v$ Secretary of State for Foreign Affairs ex $p$. The World Development Movement Ltd [1995] 1 WLR 386 (interrelationship with international development legislation).

${ }^{14}$ Elizabeth Fisher, 'Environmental Law as "Hot" Law'(2013) 25 Journal of Environmental Law 347. 
consider decision-making processes under the Planning Act 2008 regime, ${ }^{15}$ nor planning inquiries. ${ }^{16}$ These are however, worthy of scrutiny.

\section{Wind Energy and Legal Disruption}

Anthropocentric climate change is a significant source of legal disruption. ${ }^{17}$ In part that is to do with the polycentric, uncertain, and dynamic nature of climate change itself. These are issues that are relatively novel for legal systems and have implications for law-making and legal adjudication. ${ }^{18}$ But the legally disruptive nature of climate change is also to do with the fact that mitigation and adaption strategies that respond to climate change often require the creation

${ }^{15}$ See Section 2 below for an explanation. For an analysis of issues in relation to the 2008 regime. See Yvonne Rydin, Maria Lee and Simon Lock, 'Public Engagement in DecisionMaking on Major Wind Energy Projects'(2015) 27 Journal of Environmental Law 139 and Chiara Armeni, 'Participation in Environmental Decision-making: Reflecting on Planning and Community Benefits for Major Wind Farms'(2016) 30 Journal of Enviromental Law 415.

${ }^{16}$ These are primarily appeals on the merits by the Planning Inspectorate. In England see s 78 and Schedule 6 of the Town and Country Planning Act 1990 and The Town and Country Planning (Determination of Appeals by Appointed Persons) (Prescribed Classes) Regulations 1997, SI 420/1997.

${ }^{17}$ Elizabeth Fisher, Eloise Scotford and Emily Barritt, 'The Legally Disruptive Nature of Climate Change'(2017) 80 Modern Law Review 173.

18 ibid. 
of new infrastructures. ${ }^{19}$ It is this type of legal disruption that this article is concerned with. The focus is upon the building of wind turbines - a necessary part of a transition to wind energy.

As Jasanoff and Kim state, 'new energy futures will need to reconfigure the physical deep structures of civilizations - grids and pipelines, seashores and pastoral landscapes, and suburbs and cities, that were shaped by the energy choices of the past' ${ }^{20}$ The transition to wind energy requires the assembling of many things to construct this new network: the creating of a market for renewable electricity, building a supply network, and the erecting of new physical objects - wind turbines. ${ }^{21}$ Like the creation of all new infrastructures, ${ }^{22}$ creating this new infrastructural network disrupts stable and established practices. Technologies and infrastructures do not exist separately from the rest of the society. ${ }^{23}$

${ }^{19}$ Cymene Howe and Dominic Boyer, 'Aeolian Politics'(2915) 16 Distinktion: Journal of Social Theory 31 .

${ }^{20}$ Sheila Jasanoff and Sang-Hyun Kim, 'Socio-Technical Imaginaries and National Energy Policy'(2013) 22 Science as Culture 189, 189.

${ }^{21}$ On the significance of infrastructure construction see Brian Larkin, 'The Politics and Poetics of Infrastructure'(2013) 42 Annual Review of Anthropology 327, 328.

${ }^{22}$ Consider for example, the disruption that has been created by building railways. See Simon Bradley, The Railways: Nation, Network and People (Profile Books 2015).

${ }^{23}$ Trevor Pinch, 'On Making Infrastructure Visible: Putting the Non-Humans to Rights' (2010) 40 Cambridge J Economics 77, 80. 
The actors affected by wind energy are polycentric and exist at multiple levels. ${ }^{24}$ Some actors are readily identifiable (those who live near a turbine, the company operating the turbines), some are more indirect (end users of the energy, the government who achieves their renewable energy targets by deploying wind energy, other actors who are affected by what they value being put at risk), and some are quite abstract (those who benefit from mitigating climate change). The focus of disagreement in relation to wind energy has primarily been on the physical presence of wind turbines. Wind turbines are 'in a banal sense, highly visible infrastructural projects'. ${ }^{25}$ Given their atypical and prominent physical presence, differences of opinion over them 'cannot be reduced to a discursive difference'. ${ }^{26}$

A wind energy project can involve anything from a single turbine on a domestic house to a large scale offshore project of 480 turbines. They are also a distinctive form of 'development' with no physical precedents. Wind turbines can be very tall, and have large blade spans, but they are not bulky. Thus, one judge in a case noted that a turbine had an 'albeit

\footnotetext{
${ }^{24}$ This is a common feature of climate change issues. See Elinor Ostrom, 'Polycentric Systems for Coping With Collective Action and Global Environmental Change'(2010) 20 Global Environmental Change 550.
}

${ }^{25}$ Anders Blok, 'Infrastructuing New Urban Common Worlds: On Material Politics, Civic Attachments, and Partially Existing Wind Turbines' in Penelope Harvey, Casper Bruun and Atsuro Morita (eds), Infrastructure and Social Complexity: A Companion (Routledge 2016) (n 29) 105.

${ }^{26}$ Ash Amin and Nigel Thirft, Seeing Like a City (Polity Press 2017) 46. 
substantial but very slender scale'. ${ }^{27}$ Another judge in another case concluded that 'I am troubled by a turbine which will be taller than St Paul's in London' ${ }^{28}$ but also recognised it was a very different type of development from such a large building.

Law and legal processes are sites in which this disruption is particularly obvious. ${ }^{29}$ This is not just because the catalysts for infrastructural change are enshrined in law, ${ }^{30}$ but because law is having to manage the process of change, and provides forums for the inevitable disputes that arise. In regards to the former, law 'provides an envelope of social order within which new epistemic constructs and technological objects are fitted out with recognizable meanings and normative implications'. ${ }^{31}$ In regards to the latter, law provides arenas for the authoritative resolution of disputes, most obviously in the form of adjudication. In both cases, the disruption

27 Ecotricity (Next Generation) Ltd $R$ (On the Application Of) $v$ Secretary of State for Communities And Local Government [2014] EWHC 2699 [4].

${ }^{28}$ Howell v Stamford Renewables Ltd [2014] EWHC 3627 (Admin) [37]. Note he upheld the permission.

${ }^{29}$ Pinch (n 29) 79. This contrasts with the fact that in the rest of social processes they are often understood to be invisible. Blok, 'Infrastructuing New Urban Common Worlds: On Material Politics, Civic Attachments, and Partially Existing Wind Turbines' (n 25) 106.

${ }^{30}$ (n 2) and see also section 1, Climate Change Act 2008.

${ }^{31}$ Sheila Jasanoff, 'Making Order: Law and Science in Action' in Edward Hackett and others (eds), The Handbook of Science and Technology Studies (3rd edn, The MIT Press 2008) 764. 
arises because a new infrastructure and its consequences need to be reconciled with existing legal concepts and existing legal practices. ${ }^{32}$

In the UK, planning law has been an important site for legal disruption. Planning law regulates what form the built environment takes through regulating 'development'. A dense body of statute, policy and common law doctrine has developed to delineate how planning decisions should be made. ${ }^{33}$ Planning law has a diversity of objectives that are both tactical and strategic. ${ }^{34}$ The National Planning Policy Framework states that sustainable development is the 'golden thread' running through both plan-making and decision-making. Sustainable development requires consideration of economic, social and environmental issues. ${ }^{35}$ Likewise in the UK, planning permission for a 'development' is the trigger for considering a range of environmental regimes. ${ }^{36}$

As we shall in Section 2 for most wind energy projects some form of legal permission is required to erect a wind turbine. Authoritative legal decisions must be made by public authorities about where turbines can be built and the conditions they apply to their operation. Given that wind energy is a decentralised form of energy supply, the number of decisions that

${ }^{32}$ On this process of reconciliation see Bruno Latour, The Making of Law: An Ethnography of the Conseil D'etat (Polity Press 2010) 243.

${ }^{33}$ Elizabeth Fisher, Bettina Lange and Eloise Scotford, Environmental Law: Text, Cases and Materials (Oxford University Press 2013) ch 18.

${ }^{34}$ Philip Booth, Planning By Consent (Routledge 2003) 11.

${ }^{35}$ Department of Communities and Local Government, National Planning Policy Framework (2012) [14], [9].

${ }^{36}$ Fisher, Lange and Scotford, Environmental Law: Text, Cases and Materials (n 33) Ch 18. 
need to be made are numerous. As of January 2018, there have been 2026 applications for permission for wind energy projects both onshore (1960) and offshore (66) in the UK. ${ }^{37} 727$ of these are now operational, 158 are under construction, 49 are awaiting construction, and 82 planning applications have been submitted and not decided upon. 640 had their applications refused, 55 abandoned, 6 decommissioned, ${ }^{38}$ and there were 8 where permission had expired without the project being built. 301 applications were withdrawn.

As these statistics suggest, the on-the-ground delivery of wind energy projects is not straightforward. There have been many disputes and some of those have given rise to legal actions. As highlighted in the introduction there have been 137 legal challenges to wind turbine authorisation decisions in the UK since 1995. There were 4 cases before 2001, 20 cases between 2001-2009, 40 cases between 2010-2013, 47 in 2014-5, 17 cases in 2016, and 7 in 2017.

The dynamics of these disputes vary. Take for example the opposition to the granting of a consent to a large-scale wind farm in the Shetland Islands. The Scottish Ministers were in 'receipt of a total of 3881 public representations, of which 2772 were objections and 1109 were in support of the development; the objections "raised concerns on a number of subjects

${ }^{37}$ Department of Business, Energy and Industrial Strategy, 'Renewable Energy Planning Database Monthly Extract: Renewable Energy Planning Database: January 2018', https://www.gov.uk/government/publications/renewable-energy-planning-database-monthlyextract accessed 18 February 2018. Note that overall there have been 5048 applications in relation to renewable energy projects.

${ }^{38}$ The lifespan of a wind energy project is typically 25 years. 
including habitat, wildlife, visual impact and infrastructure"' ${ }^{39}$ In contrast, Trump International opposed the building of a wind farm in sight of its golf course off the North-East coast of Scotland. Donald Trump in a letter to the first Minister of Scotland stated that 'For the record taxing your citizens to subsidize wind projects owned by a foreign energy company will destroy your country and its economy'. ${ }^{40}$ After losing the case, a spokesman for the Trump Organisation stated that the 'outcome demonstrates the foolish, small-minded and parochial mentality which dominates the current Scottish Government's dangerous experiment with wind energy'. ${ }^{41}$ In contrast again, in Tegni Cymru Cyf $v$ The Welsh Ministers, ${ }^{42}$ a proposed wind farm in Wales was rejected by a Planning Inspector because 'The cumulative effect of this proposal together with the existing and consented turbines would result in the local community having the appearance of becoming increasingly surrounded by turbines on all the high ground

${ }^{39}$ See Sustainable Shetland v Scottish Ministers [2015] UKSC 4, [8].

${ }^{40}$ Libby Brooks, 'Mad Alex': Donald Trump Letters Abuse Scottish Ex-first Minister' The Guardian (London 21 December 2016), https://www.theguardian.com/usnews/2016/dec/21/mad-alex-donald-trump-letters-abuse-ex-scottish-first-minister accessed 17 May 2018.

${ }^{41}$ Alan Tovey, 'Donald Trump Loses Battle to 'Protect' Scottish Golf Course from Wind Farm' $\begin{array}{llll}\text { The } & \text { Telegraph } & \text { (London 2015), }\end{array}$ http://www.telegraph.co.uk/finance/newsbysector/energy/12053262/Donald-Trump-losesbattle-to-protect-Scottish-golf-course-from-wind-farm.html accessed 17 May 2018.

${ }^{42}$ Tegni Cymru Cyfv The Welsh Ministers [2010] EWCA Civ 1635. 
to the south and west'. That cumulative effect would also result in 'a level of harm' in relation to noise disturbance which would conflict with planning policy. ${ }^{43}$

Overall, building a wind turbine raises questions about how acceptable they are as a form of development, particularly in terms of the impacts of the physical presence of wind turbines on the environment. Thus, as seen above, concerns about noise, visual amenity and the impact on nature arise. But the building of wind turbines also raise questions about how decisions should be made about them and how planning law should regulate them. Indeed, as we shall see, these issues dominate the case law. Many of these issues are the normal issues that are raised in planning law. But as wind turbines are a distinctive form of development, both in regards to their physical nature and purpose, they also raise a set of novel issues and existing law does not always provide templates for how decisions should be made. Thus in Tegni Cymru Cyf, Carnwath LJ (as he then was) noted that it was surprising that policy guidance didn't deal with the problems of duration and cumulative impact raised in that case. ${ }^{44}$

The account of law sketched so far points to its significant role. That significance will become even more obvious in Sections 3 to 4, but before turning to an analysis of the law it should be noted that planning law is often understood in instrumental terms by both policy makers and legal scholars. Thus, in policy, planning law, both in relation to decision-making and legal disputes, is often understood as a barrier to the effective 'delivery' of renewable

\footnotetext{
${ }^{43}$ As quoted in ibid [9], [10].

44 ibid, [40].
} 
energy. ${ }^{45}$ As the Coalition Government stated as part of their renewable energy strategy in 2011:

We recognise the need to ensure that projects have as many benefits and as few adverse impacts as possible in financial, economic and environmental terms. However, delays in the planning process or difficulties in discharging conditions attached to consents can have a significant impact on deployment. This can impact across the range of technologies both on and offshore. ${ }^{46}$

This characterisation of law has primarily been due to the fact that much discussion about energy transitions has been about ensuring they occur in light of the need to take prompt action in relation to climate change. ${ }^{47}$ There has thus been ongoing policy attempts to 'speed up' the process and to create mechanisms to ensure that local government 'delivers' renewable energy projects. ${ }^{48}$ The creation of regional renewable energy targets in Planning Policy Statement 22: Renewable Energy (2004) which operated under the Labour government is one example. The passing of the Planning Act 2008 (see Section 3 below) is another. ${ }^{49}$

${ }^{45}$ Georgina Crowhurst and Simone Davidson, 'Planning: A Roadblock to Renewable Energy in the UK' (2008) 10 Env L Rev 181, 188. Louise Smith, Planning for Onshore Wind (House of Commons Library Briefing Paper No 04370, 13 July 2016), 4.

${ }^{46}$ Department of Energy and Climate Change (n 9) 27.

${ }^{47}$ Office of the Deputy Prime Minister, Planning Policy Statement 22: Renewable Energy (2004) 8. For a discussion see Trinick (n 4) 101.

${ }^{48}$ HM Government, The UK Renewable Energy Strategy (Cm 7686, July 2009) 14 and Department of Energy and Climate Change (n 46) 30, 35.

${ }^{49}$ Crowhurst and Davidson (n 45) 193. 
An instrumental understanding of planning law has also tended to dominate in legal scholarship, primarily due to the work of Patrick McAuslan in the 1970s and 1980s. ${ }^{50}$ McAuslan understood the common law as upholding an ideology of private property, but he also understood the broader field of planning law as upholding public interest and public participation ideologies. ${ }^{51}$ This conclusion is perhaps not surprising given the way in which his analysis cleaved to the history of planning law and began with a focus on the area of compulsory acquisition and clearance orders. ${ }^{52}$ Overall, his scholarship was an example of what Harlow and Rawlings described as 'green light' administrative law scholarship ${ }^{53}$ or what Martin Loughlin has called the 'functionalist' style ${ }^{54}$ of administrative law scholarship. ${ }^{55}$ For McAuslan, law, and in particular the common law, 'had a good deal to answer for in respect

${ }^{50}$ See in particular, McAuslan, The Ideologies of Planning Law (n 12). For examples of the current influence see Emma Lees and Edward Shepherd, 'Morphological Anaysis of Legal Ideology: Locating Interpretive Divergence'(2018) 10 Journal of Property, Planning, and Environmental Law 51and Emma Lees and Edward Shepherd, 'Incoherence and Incompatibility in Planinng Law '(2015) 7 International Journal of Law and the Built Environment 111.

${ }^{51}$ McAuslan, The Ideologies of Planning Law (n 12).

52 ibid.

53 Carol Harlow and Richard Rawlings, Law and Administration (3rd edn, Cambridge University Press 2009) Ch 1.

${ }^{54}$ Martin Loughlin, Public Law And Political Theory (Clarendon Press 1992) 201-5.

${ }^{55}$ Patrick McAuslan, ‘Administrative Law, Collective Consumption and Judicial Policy'(1983) 46 Modern Law Review 1. 
of' what he saw as 'the present malaise of town planning'. ${ }^{56}$ Not only did it uphold private property rights, but he also saw it as too complex and giving too much discretionary power to administrative decision-makers. ${ }^{57}$

While Loughlin opined in 1986 that 'Today there is little excuse for holding crude views concerning the relationship between law and the planning system', ${ }^{58}$ since then, planning law scholarship has been primarily the province of reflective practitioners writing in specialist journals in response to specific cases. ${ }^{59}$ This is despite the fact that both planning law and administrative law have been transformed in the intervening period. Planning law has not only undergone a series of significant legal and policy reforms, ${ }^{60}$ but has also become a major conduit for the delivery of other areas of regulation, specifically environmental regulation. ${ }^{61}$

${ }^{56}$ JPWB McAuslan, 'Planning Law's Contribution to the Problems of an Urban Society'(1974)

37 Modern Law Review 134, 152.

${ }^{57}$ Ibid.

${ }^{58}$ Martin Loughlin, 'Planning Law: Through the Texts Darkly' (1986) 1 Planning Practice and Research 31, 32.

${ }^{59}$ Its notable that only one article has ever been published on planning law in the OJLS - in its first issue, Martin Loughlin, 'Planning Gain: Law, Policy and Practice' (1981) 1 OJLS 61.

${ }^{60}$ In relation to legislation see the TCPA Act 1990, the Planning and Compulsory Purchase Act 2004, Planning Act 2008, and the Localism Act 2011. In regards to policy, Planning Policy Guidance was replaced by Planning Policy Statements which were then replaced by the National Planning Policy Framework in 2012. See Robert Duxbury, Telling \& Duxbury's Planinng Law and Procedure (Oxford University Press 2018) 41-2.

${ }^{61}$ Fisher, Lange and Scotford, Environmental Law: Text, Cases and Materials (n 33). 
More significantly, since the procedural reforms to judicial review in the 1980s, judicial review doctrine has evolved into a rich and complex body of doctrine, that if anything is often understood to be more about a range of public law values rather than private rights. ${ }^{62}$

\section{Planning Law Frameworks and Wind Energy}

Discussing planning law and administrative law scholarship is getting ahead of myself however. What is needed before such a discussion is to explore in more detail the significant role that planning law is playing in an energy transition. That role has two aspects: the creation of frames that regulate what is a wind energy development and when, where and how it can be built; and the resolution of disputes that arise in relation to wind energy development. The first role is considered in this section and the second in the next section.

As a number of scholars have shown, law plays an important role in 'demarcating' regulatory objects. ${ }^{63}$ For example Jasanoff has described how laws and the problems they are regulating are co-produced. ${ }^{64}$ As Lidskog, Uggla and Soneryd note 'Regulation explicitly or implicitly creates demarcations and boundaries that make objects appear hazardous or

\footnotetext{
${ }^{62}$ A good and accessible account of this is in Stephen Sedley, Lions Under the throne: Essays on the History of English Public Law (Cammbridge University Press 2015).

63 Javier Lezaun, 'Creating a New Object of Government: Making Genetically Modified Organisms Traceable'(2006) 36 Social Studies of Science 499.

${ }^{64}$ Sheila Jasanoff, Designs on Nature: Science and Democracy in Europe and the United States (Princeton University Press 2005).
} 
harmless, safe or risky, natural or unnatural, important or unimportant' ${ }^{65}$ Stokes has shown the complexity and multiplicity of these frames in relation to fracking and the ways in which they are both flexible and fixed and synoptic and specific. ${ }^{66}$ Hilson has examined how planning law frames fracking. ${ }^{67}$ Overall, what these studies show is how legal and regulatory frameworks structure our understanding of the world and what is deemed to be important or unimportant in it.

That process is rarely happening on a blank sheet. Thus, while wind turbines are a distinctive form of development, there is no autonomous law relating to the building of wind turbines. Rather, the building of wind turbines is accommodated, either explicitly or implicitly, into existing regimes in the legal system which in turn frames understandings of what is an acceptable wind turbine development. Given that wind turbines can be built onshore or offshore there are different starting points for these processes of accommodation. Devolution has also shaped the law in this area. ${ }^{68}$ For ease of analysis, I focus on the English frameworks in this

${ }^{65}$ R Lidskog, Y Uggla and L Soneryd, 'Making Transboundary Risks Governable: Reducing Complexity,Constructing Spatial Identity, and Ascribing Capabilities'(2011) 40 AMBIO 111, 112.

${ }^{66}$ Elen Stokes, 'Regulatory Domain and Regulatory Dexterity’(2016) 79 Modern Law Review 961.

67 Hilson, 'Framing Fracking: Which Frames Are Heard in English Planning and Environmental Policy and Practice?' (n 10).

${ }^{68}$ Thomas Muinzer and Geraint Ellis, 'Subnational Governance for the Low Energy Transition: Mapping the UK's "Energy Constitution"'(2017) 35 Environment and Planning C: Government and Policy 1176. 
section, most of which are mirrored in some way in the devolved regions. In other words, the discussion here is illustrative of what legal frameworks do rather than a definitive mapping of wind energy related planning law in the UK. In the next section however, I will consider case law from across the UK.

For the building of an onshore wind turbine, the fundamental starting point is that it is a 'building operation' and thus 'development' which requires some form of state consent before it can be built legally. ${ }^{69}$ Planning law operates at the local level. Local planning authorities (LPAs) develop local plans (known also as development plans). ${ }^{70}$ Section $70(2)$ of the Town and Country Planning Act 1990 (TCPA 1990) places the following obligations on LPAs in relation to planning applications:

In dealing with such an application the authority shall have regard to the provisions of the development plan, so far as material to the application, and to any other material considerations.

'Material considerations' are 'any consideration which relates to the use and development of land ${ }^{71}$ and also national planning policy ${ }^{72}$ which includes specific guidance developed in

${ }^{69}$ Section 57, Town and Country Planning Act 1990.

70 The process for making them is in Pt 2, Planning and Compulsory Purchase Act 2004.

${ }^{71}$ Stringer v Minister for Housing and Local Government [1970] 1 WLR 1281, 1294.

${ }^{72}$ Department for Communities and Local Government, National Planning Policy Framework (2012) [11-13]. 
relation to wind energy. ${ }^{73}$ The granting of planning permission is a process that is discretionary in which 'planning judgement' is understood to play a central role. ${ }^{74}$ As we shall see in Section 4.2, in deciding to grant planning applications, LPAs must also take into account legal obligations under other pieces of legislation. This not only reflects the multiple aims of planning law, but also the way in which decision-making in planning triggers other legal regimes. ${ }^{75}$

As touched upon above, LPAs are required to consider national guidance. ${ }^{76}$ The National Planning Policy Framework 2012, itself a material consideration, states that one of the 12 'core planning principles' is that planning 'support the transition to a low carbon future in a changing climate......and encourage the use of renewable resources (for example, by the development of renewable energy)' ${ }^{77}$ There is also a National Planning Statement for Renewable Energy Infrastructure, that is primarily relevant to decision-making under the

73 Department of Communities and Local Government, Planning Practice Guidance: Renewable and Low Carbon Energy, https://www.gov.uk/guidance/renewable-and-lowcarbon-energy accessed 22 May 2018, Paragraph: 014 Reference ID: 5-014-20150618.

${ }^{74}$ Tesco Stores Ltd v Secretary of State for the Environment [1995] 1 WLR 759, 780.

${ }^{75}$ Fisher, Lange and Scotford, Environmental Law: Text, Cases and Materials (n 33) ch 18.

${ }^{76}$ Of many different sorts. See ibid, 806-810.

77 Ministry of Housing, Communities \& Local Government, National Planning Policy Framework (2012), [17] < https://www.gov.uk/government/collections/planning-practiceguidance> accessed 20 February 2018. 
Planning Act 2008 as discussed below, but is also a material consideration for LPAs. ${ }^{78}$ The Ministry of Housing, Communities \& Local Government has also produced further planning practice guidance for renewable energy projects. $^{79}$

Inherent in the planning structure is also a process of appeals to the Secretary of State that are usually then directed to the Planning Inspectorate for consideration. ${ }^{80}$ Common law judicial review challenges and statutory legal challenges ${ }^{81}$ can also be made to the High Court. As shown in Section 4, there is a rich body of precedent, some of it legally binding, some of it practically binding, and some of it as examples of good practice.

What I have just described is only a starting point however. Delegated legislation has deemed some domestic wind turbines that are 'development' as 'permitted development' under the General Permitted Development Order regime and thus not requiring planning

${ }^{78}$ Department of Energy and Climate Change, National Policy Statement for Renewable Energy Infrastructure (EN-3) (July 2011), 1.

${ }^{79}$ Ministry of Housing, Communities \& Local Government Planning, Practice Guidance: Renewable Low Carbon Energy, http://planningguidance.communities.gov.uk/blog/guidance/renewable-and-low-carbonenergy/particular-planning-considerations-for-hydropower-active-solar-technology-solarfarms-and-wind-turbines/\#paragraph_015 accessed 25 March 2018.

\footnotetext{
${ }^{80}$ Section 78 TCPA 1990.

${ }^{81}$ Section 288 TCPA 1990.
} 
permission. ${ }^{82}$ This change was introduced in $2011^{83}$ after a process of consultation. ${ }^{84}$ In the consultation process it was noted that:

The planning system can play an important role in helping to shape their development in ways that ease their absorption into our existing urban and rural landscapes and guard against undue impacts for example on neighbouring occupiers or the historic environment. ${ }^{85}$

The framing role of law can be seen in this statement. The role of legal change is to 'ease' the 'absorption' of wind turbines into 'existing urban and rural landscapes'. Thus, the consultation proposing the new Order focused on the need to 'accommodate new and more environmentally sustainable technologies', while at the same time managing their impact. ${ }^{86}$

${ }^{82}$ See Town and Country Planning (General Permitted Development) (England) Order 2015 SI No $596 . \quad$ See the guidance here https://www.planningportal.co.uk/info/200130/common_projects/57/wind_turbines accessed 20 February 2018.

${ }^{83}$ The Town and Country Planning (General Permitted Development) (Amendment) (England) Order 2011 SI No 2056.

${ }^{84}$ See the documents at https://www.gov.uk/government/consultations/development-rightsfor-small-scale-renewable-and-low-carbon-energy-technologies-and-electric-vehiclecharging-infrastructure accessed 20 February 2018.

${ }^{85}$ Department of Communities and Local Government, Permitted Development Rights for Small-scale Renewable and Low-carbon Energy Technologies, and Electric Vehicle Charging Infrastructure: Consultation (2009) 10.

${ }^{86}$ Ibid 14. 
But this Order is doing more than just promoting wind turbines. It sets out quite prescriptive requirements about what type of turbines fall into the permitted development category. ${ }^{87}$ These include requirements about the technical specifications of a wind turbine and where it is sited. What can be seen in relation to permitted development rights is thus the normalising of a particular category of wind energy technology - a category very closely circumscribed, and as the consultation document makes clear, ${ }^{88}$ only after an analysis of the impacts of the technology.

At the other end of the spectrum are onshore wind energy developments that produce over 50MW. While the output capacity of turbines varies, this usually includes projects where there are 20 turbines or above. Under the Planning Act 2008, until March 2016, these were designated 'nationally significant infrastructure projects' and thus subject to a centralised planning permission process for 'development consent', ${ }^{89}$ framed by 'National Policy Statements (NPS), "designed to specify and emphasize the "need" for the infrastructure categories concerned and thereby prevent such "generic" or "policy issues" being contested at successive project-specific inquiries'. ${ }^{90}$ The consideration of consent for these projects was

\footnotetext{
87 (n 45) Pt 14, Class H.
}

${ }^{88}$ Department of Communities and Local Government, Permitted Development Rights for Small-scale Renewable and Low-carbon Energy Technologies, and Electric Vehicle Charging Infrastructure: Consultation (n 85).

${ }^{89}$ Planning Act 2008 as amended by the Localism Act 2011.

${ }^{90}$ Pt 2, Planning Act 2008. See Maria Lee and others, 'Public Participation and Climate Change Infrastructure'(2013) 25 Journal of Environmental Law 33 for an overview. Tim Marshall and 
initially carried out by the Planning Inspectorate who made a recommendation to the Secretary of State. ${ }^{91}$ A major impetus for the Planning Act 2008 was concerns about delay in the mainstream planning process. In part the delay was addressed by a schedule for deciding consents ${ }^{92}$ and in part by the NPSs changing the structure of the process and discourse around consent. ${ }^{93}$

The Act does little to define what a 'nationally significant infrastructure project' (NSIP) is in conceptual terms. The adjectival phrase 'nationally significant' is thus doing much of the work, embodying as it does assumptions about what is a justification for reconfiguring the consent discourse. In the Act the NSIP definition lists a set of developments that fall into the category and then also lists 'fields' (eg waste, energy, water) where the Secretary of State may designate further NSIPs. ${ }^{94}$ As wind energy developments were only NSIPs if their output exceeded 50MW, the justification for falling into the NSIP category related to what they provided, not to criteria related to the way they used land. Part of the 2015 Conservative

Richard Cowell, 'Infrastructure, Planning, and the Command of Time'(2016) 34 Environment and Planning C: Government and Policy 1843

${ }^{91}$ Note that this process of consideration 'disapplies' the consent required under s 36 of the Electricity Act 1989 https://www.gov.uk/guidance/consents-and-planning-applications-fornational-energy-infrastructure-projects accessed 5 March 2018.

92 Section 107, Planning Act 2008.

${ }^{93}$ For a discussion of that process see Lee and others, 'Public Participation and Climate Change Infrastructure' (n 90) and Rydin, Lee and Lock, 'Public Engagement in Decision-Making on Major Wind Energy Projects' (n 15).

${ }^{94}$ Section 14. 
Manifesto was to shift onshore projects over 50MW from the Planning Act 2008 to the mainstream planning regime. That occurred in early $2016 .{ }^{95}$ This transferral was understood to be about 'giving local people the final say over onshore wind farm applications'. ${ }^{96}$ The government stated that 'Any application to build wind turbines will then need to have the clear backing of the community - with any planning concerns clearly addressed' ${ }^{97}$ Given the above, this statement is misleading. What the reform was effectively doing was shifting these projects from one legal regime to another so that a different set of processes and legal doctrines will apply.

Finally, most offshore wind energy projects are above 50MW and thus are usually designated NSIPs under the Planning Act 2008. The June 2015 and March 2016 reforms did not alter the consent procedure for these developments. What makes these into a separate

${ }^{95}$ Onshore Wind Generating Stations (Exemption) (England and Wales) Order 2016 No 450 of 2016. See also The Infrastructure Planning (Onshore Wind Generating Stations) Order 2016 (No 306 of 2016) and The Onshore Wind Generating Stations (Exemption) (England and Wales) Order 2016 (No 21 of 2016) and s 78 of the Energy Act 2016 which amends s 36 of the Electricity Act 1989 so that it does not apply to 'an English or Welsh onshore wind generating station'.

${ }^{96}$ DECC, 'Press Release, Giving Local People the Final Say over Onshore Wind Farms' 18 June 2015, https://www.gov.uk/government/news/giving-local-people-the-final-say-overonshore-wind-farms accessed 20 February 2018.

${ }^{97}$ Ibid. 
category is their geographical and thus jurisdictional location. ${ }^{98}$ The offshore nature of these projects means that they are not, as a starting point, governed by planning law. Moreover, they require a lease from the Crown Estate, these leases being granted in a series of 'Rounds'. ${ }^{99}$ Since 2009 the National Maritime Organisation also plays a central role in the consent process.

What is clear from this brief overview is that planning law is a dense and detailed legislative and institutional space. Different types of legislation, delegated legislation, and policy are constructing understandings of what is a legally acceptable wind turbine project and how decisions should be made in relation to such projects. Law is not just a catalyst for wind energy but also constituting it through creating a series of 'demarcations' and boundaries' so as to delineate what is an acceptable regulatory object. ${ }^{100}$ Legal frameworks are framing understandings of wind turbines as regulatory objects and in doing so regulating how these different categories of wind energy developments are understood and how these different categories of wind turbines are considered.

${ }^{98}$ Although note the demarcation is not always straightforward. See Redcar and Cleveland Borough Council, R (on the application of) v EDF Energy (Northern Offshore Wind) Ltd [2008] EWHC 1847 (Admin) which involved offshore turbine and onshore building operations.

99 See Christopher Barclay, Wind Farms Consents - Offshore (House of Commons Note SN/SC/5088 17 July 2012), 2.

100 Lidskog, Uggla and Soneryd, 'Making Transboundary Risks Governable: Reducing Complexity,Constructing Spatial Identity, and Ascribing Capabilities' (n 65) 112 and Elizabeth Fisher, 'Chemicals as Regulatory Objects'(2014) 23 Review of European, Comparative and International Environmental Law 163. 
In regards to mainstream planning law, a wind energy project is another type of 'development' that needs permission from a LPA and in granting permission a range of considerations apply. Those wind turbines that fall into the permitted development category are defined and regulated within narrow constraints that prescribes the use of technology. In contrast if a wind energy development is legally classified as a NSIP, that results in a different set of processes applying. In all cases, the logic behind the classifications reflect different starting points and assumptions that already exist in the legal order - about electricity generation, about development, and about jurisdiction.

\section{Legal Challenges to Wind Energy Developments}

That is not the only role of law however. The legal frameworks above leave much open to question. For example, how relevant are existing planning law precedents? How should new laws or new policies be interpreted? How should decisions to build turbines be integrated with other legal rights, obligations and duties? Moreover, most of these frameworks grant discretion to decision-makers and the question arises concerning how such discretion should be exercised.

There are many different forums in which responses to these questions are developed. As already touched upon, guidance may be given in policy (although policy will need interpretation). Ways of addressing these issues may also be developed in informal administrative practices and in planning inspector's reports. The most significant forums from a legal perspective are legal challenges to mainstream planning decisions about wind turbines. 
Some of these are common law judicial review challenges and others are statutory challenges for errors of law. ${ }^{101}$ For my purposes, there is no difference between these procedural routes. ${ }^{102}$

\subsection{An Overview of the Case Law}

As noted above there were 137 such challenges between 1995 and the end of 2017. As also noted the number of cases reached a peak in 2014-5. Beyond this, a statistical analysis of these different cases is of limited use. A number of cases are cases on appeal, ${ }^{103}$ repeat litigation, ${ }^{104}$ or litigation on related issues ${ }^{105}$ thus giving rise to a problem of double counting. Cases are brought by a range of litigants including members of the local community, ${ }^{106}$ national non-

${ }^{101}$ Eg 288 TCPA 1990.

102 See the comments of Ev Secretary of State for the Home Department [2004] EWCA 49 CA.

${ }^{103}$ There are many examples of this. See for example, Trump International Golf Club Scotland Ltd v The Scottish Ministers [2014] ScotCS CSOH_221; Trump International Golf Club Scotland Ltd v The Scottish Ministers [2015] ScotCS CSIH_461; and Trump International Golf Club Scotland Ltd v The Scottish Ministers [2015] UKSC 74.

104 Williams, $R$ (on the application of) v Powys County Council [2016] EWHC 480 (Admin) [3].

${ }^{105}$ Eg Packard, Petitioner [2011] CSOH 148.

${ }^{106}$ Eg Skye Windfram Action Group Limited: Re Judicial Review [2008] CSOH 19 and FinKelcey v Milton Keynes Borough Council [2008] EWHC 1650 (Admin). 
governmental organisations, ${ }^{107}$ and wind energy companies, ${ }^{108}$ but in many cases other parties are joined. ${ }^{109}$ While many of those challenging the building of wind turbines are 'local', they are 'local' in a range of ways. Some run local businesses, ${ }^{110}$ but Trump Corporation is not easily comparable with a land owner operating a yurt as a tourist business. ${ }^{111}$ Some are local landowners, but landowners vary in what they own and how long they have lived in the area. ${ }^{12}$ The concerns of local parties also vary - some are concerned about local amenity issues, ${ }^{113}$

${ }^{107}$ Royal Society for the Protection of Birds $v$ T \& Ors $v$ The Scottish Ministers [2017] ScotCS CSIH_31.

${ }^{108}$ Ecotricity (Next Generation) Ltd $v$ Secretary of State for Communities \& Local Government [2015] EWCA Civ 657 and RWE Npower Renewables Ltd, $R$ (on the application of) $v$ Ecotricity (Next Generation) Ltd [2013] EWHC 751 (Admin).

${ }^{109}$ Barnwell Manor Wind Energy Ltd v East Northamptonshire District Council [2014] EWCA Civ 137 in which the National Trust and English Heritage joined as parties.

${ }^{110}$ Williams, $R$ (on the application of) (n 104) The applicant operated leisure activities.

${ }^{111}$ Martin v Secretary of State for Communities and Local Government [2015] EWHC 3435 (Admin) and Trump International Golf Club Scotland Ltd (n 103).

${ }^{112}$ Compare the 'significant land owners' [2] in Benacre Estates Company v Secretary of State for Communities and Local Government [2009] EWHC 680 (Admin) with the claimant in Hubert who had been a resident for 40 years see Hubert $v$ Carmarthenshire County Council [2015] EWHC 2327 (Admin) .

113 The Friends of Hethel Ltd, R (on the application of) v Ecotricity [2009] EWHC 2856. 
others about protecting economic interests, ${ }^{114}$ and others again about the nature and structure of the wind energy industry. ${ }^{115}$

The histories of these actions also vary. In some cases, a third party is bringing a judicial review action challenging the decision of an LPA granting planning permission to a wind energy project. ${ }^{116}$ Many are where a developer is challenging the refusal of planning permission. ${ }^{117}$ Others are where there has been a line of decisions - a planning officer has recommended granting permission, a local planning committee did not follow that guidance, and there was an appeal to a planning inspector who came to a different conclusion. ${ }^{118}$

Given all this, focusing on the outcome of cases is also of limited use. In 62 cases a judicial review challenge or statutory challenge was dismissed resulting in the upholding of the grant of planning permission and in 26 the challenge was dismissed upholding the refusal of planning permission. In 22 cases a challenge to planning permission was allowed resulting in the quashing of that permission and/or a declaration and in 7 cases a challenge to the refusal of planning permission was allowed quashing the refusal of permission. In 12 other cases, a range

${ }^{114}$ Trump International Golf Club Scotland Ltd (n 111).

115 Joicey, R (on the Application of) v Northumberland County Council [2014] EWHC 3657 $[3]$.

${ }^{116}$ Lancashire, $R$ (on the application of) $v$ Northumberland County Council [2013] EWHC 3850 (Admin).

${ }^{117}$ Ecogen Developments Ltd, $R$ (on the application of) v Secretary Of State For Trade \& Industry [2002] EWCA Civ 1433.

${ }^{118}$ See the history of Tegni Cymru Cyf ( n 42). 
of other issues were raised including applications for Protective Costs Orders. ${ }^{119}$ Again double counting due to appeals and repeat litigation need to be kept in mind. Likewise, the fact that these cases engage different legal issues means that any comparison is not comparing like with like. Thus, while clearly these outcomes show that the courts tend to maintain the status quo by not upholding challenges, care needs to be taken beyond that. For example, the likelihood of the success of a challenge is similar - $26 \%$ of planning permissions challenged were quashed and $21 \%$ of planning refusals were quashed.

Much more significantly, the outcome of these cases is not the focus of the reasoning in them. As constantly stressed by judges in these cases, judicial review is not merits review. ${ }^{120}$ The role of a court in a judicial review challenge is not to remake the decision or to re-find the facts but to ensure that the decision-maker has not committed an error of law, and if they have, decide what type of remedy should be ordered, if any. Thus, while judicial review challenges are often driven by particular interests and judges recognise that '[w]ind turbines generate passionate argument', ${ }^{121}$ the arguments before the court are required to be legal arguments and there are limits to the 'procedural games' parties can play. ${ }^{122}$ The focus is upon the legal frame and the legal questions that arise. As shall be shown below, they require a barrister to show how such grounds relate to the legal and policy context, the development at hand, and existing

${ }^{119}$ Eaton v Natural England [2012] EWHC 2401 (Admin).

${ }^{120}$ Eg Newark \& Sherwood District Council v Secretary of State for Communities and Local Government [2013] EWHC 2162 (Admin) [10] and Lancashire, $R$ (on the application of) (n 116) [13].

121 RWE Npower Renewables Ltd, R (on the application of) (n 108) [1].

${ }^{122}$ Ecogen Developments Ltd, $R$ (on the application of) (n 117) [11]. 
legal doctrine. Or to put the matter another way, planning decisions about wind turbines need to be reconciled with the expectations of the legal order.

One stark example of the 'legalness' of these cases is the judicial review challenge by Trump International Golf Club Scotland Ltd to a wind energy development off the coast of Scotland. This case concerned consent given under section 36 of the Electricity Act 1989 and the focus of the challenges were on the statutory construction of that Act, the way in which consent conditions should be interpreted, and in the lower courts, other grounds of review. ${ }^{123}$ In all cases, the court was relating the arguments put to the court to pre-existing doctrine. Thus, for example, it was argued by the petitioners in the Scottish Outer House that there was evidence of apparent bias due to a remark made by a Minster at a social event being recorded by a writer on their blog. No legal weight was given to this as it was not relevant to the legal test. As Lord Doughty noted in the Outer House:

In my opinion, properly considered in their context, the relevant circumstances would not raise in the hypothetical observer's mind the real possibility of bias on the part of the decision-maker. ${ }^{124}$

Existing legal doctrine placed no weight on the comment because '[a]ll of this occurred on a social occasion no doubt dedicated to the appreciation of golf' ${ }^{125}$ It had no legal significance.

The 'legalness' of these decisions might give rise to a perception that this case law is just an exercise in legal evasion - the transformation of a genuine dispute over the local impact

123 (n 103).

124 Trump International Golf Club Scotland Ltd (OH) (n 103) [100].

125 Trump International Golf Club Scotland Ltd (IH) (n 103) [37] per Lord President. 
into a question of legal technicality. ${ }^{126}$ That characterisation can also encourage a view that these cases are examples of parties using courts to obstruct or to facilitate a decision and nothing more. ${ }^{127}$ But that ignores the fact that challenges as legal challenges relate to legal uncertainties and questions that arise because of the disruption that an a-typical development such as the building of wind turbines create for the detailed legal space that is planning law. ${ }^{128}$

Given the diversity and complexity of the legal frameworks for wind turbines charted in Section 3 (which only covered England), it is inevitable that different wind energy projects give rise to different legal issues. What is a 'material consideration' for a wind energy project built near a National Park where there is a National Park Authority's Renewable Energy Supplementary Planning Guidance ${ }^{129}$ is distinct from a project built in a rural area where a Landscape Character Assessment and Landscape Sensitivity Assessment have been undertaken. ${ }^{130}$ Decision-making that engages the Electricity Act $1989^{131}$ is operating under a

126 This for example was McAuslan's critique of planning law in the early 1970s. See McAuslan, 'Planning Law's Contribution to the Problems of an Urban Society' (n 56).

${ }^{127}$ See that view in an article such as Carol Harlow, 'Public Law and Popular Justice'(2002) 65 Modern Law Review 1

${ }^{128}$ See the judicial recognition of that in Simson v Aberdeenshire Council [2006] CSOH 49, [25].

${ }^{129}$ Rhoscrowther Wind Farm Ltd $v$ Welsh Ministers [2016] EWHC 1388 (Admin).

${ }^{130}$ Ecotricity Next Generation Ltd $v$ Secretary of State for Communities and Local Government [2015] EWHC 189 (Admin).

${ }^{131}$ Ecogen Developments Ltd, $R$ (on the application of) (n 117). 
different legal regime than that under the Planning Act 2008. ${ }^{132}$ This is another reason why statistical analysis of the case law is of limited use. It also means it is impossible to identify a paradigm example of a case.

What is striking however is that relatively few grounds of review directly relate to the physical nature of a wind turbine project itself. While most of these cases open with a physical account of the wind energy project - 'The 30 wind turbines have a maximum tip height of 130 metres and will be positioned in three rows, approximately 600 metres apart, each containing ten turbines' ${ }^{\prime 33}$ and planning permission was granted for 'the erection of a wind turbine (with a hub height of 50 metres and 66 metres to tip), ${ }^{134}$ being typical descriptions - the physical features often recede into the background. While some grounds of challenge relate to geographically local impacts (eg noise), ${ }^{135}$ many do not, and what is understood as an 'unacceptable' local impact is often regulated by national standards and policy. ${ }^{136}$ It is thus the

${ }^{132}$ Powys County Council v The Welsh Ministers [2015] EWHC 3284 (Admin)

${ }^{133}$ Redcar and Cleveland Borough Council, $R$ (on the application of) (n 98) [1].

${ }^{134}$ Holder, $R$ (on the application of) $v$ Gedling Borough Council [2013] EWHC 1611 (Admin) $[2]$.

${ }^{135}$ Newark \& Sherwood District Council (n 120) [4].

$136 \mathrm{Eg}$ see noise standards in Ministry of Housing, Communities \& Local Government Planning, Practice Guidance, Renewable and Low Carbon Energy, Paragraph: 015, Reference ID: 5-015-20140306, $\quad$ Revised 6 2014, http://planningguidance.communities.gov.uk/blog/guidance/renewable-and-low-carbonenergy/particular-planning-considerations-for-hydropower-active-solar-technology-solar- 
interpretation of the national standard that is the subject of dispute. ${ }^{137}$ This is not surprising. As we saw in Section 3, legal frameworks regulate the general contours of wind energy projects as regulatory objects.

Instead, many of these challenges primarily relate to how to incorporate decisionmaking about a wind energy project into the wider legal framework. The legal questions before the court concern a series of legal issues that arise from specific decisions. Broadly speaking, the grounds of review cluster into three main groupings: grounds that relate to other legislative schemes, grounds that relation to the interpretation of specific policies and planning conditions; and grounds that relate to how decisions about wind energy projects should be made. Many of these challenges are not successful, but given the permission requirement in a judicial review action, they are arguable. ${ }^{138}$ In all cases, courts are required to relate the arguments made to existing doctrine, whether specific to planning law or more general administrative law doctrine.

\subsection{Relationship with Other Legislative Schemes}

In many of these cases, after describing the number and nature of the wind turbines involved in the development, the next step is to describe their location in regards to legally designated enclaves of landscape protection or nature conservation. These may include National Parks, ${ }^{139}$

farms-and-wind-turbines/\#paragraph 015 accessed 25 March 2018 which refers to ETSU-R97: The Assessment and Rating of Noise from Wind Farms as guidance.

${ }^{137}$ Tegni Cymru Cyf(n 42).

${ }^{138}$ C.f. Rhoscrowther Wind Farm Ltd (n 129) [24].

${ }^{139}$ Barnes $v$ Secretary of State for Communities and Local Government [2010] EWHC 1742 (Admin) [1]. 
World Heritage sites, ${ }^{140}$ Wild Land, ${ }^{141}$ Areas of Outstanding National Beauty, ${ }^{142}$ Green Belt land, ${ }^{143}$ Conservation Areas, ${ }^{144}$ Listed Buildings, ${ }^{145}$ areas protected under EU nature conservation regimes, ${ }^{146}$ and even specific legislated regimes such as the Norfolk and Suffolk Broads Act. ${ }^{147}$ Much of the legal argument then focuses upon whether the building of the wind turbine leads to a failure to uphold legal obligations as set out in national legislation in relation to those areas.

140 Mageean, $R$ (on the application of) $v$ Secretary of State for Communities \& Local Government [2010] EWHC 2652 (Admin) .

${ }^{141}$ Glenmorie Wind Farm Ltd, Re Judicial Review [2016] ScotCS CSOH_34 [2] and Wildland Ltd $v$ The Scottish Ministers [2017] ScotCS CSOH_113.

142 Mageean, $R$ (on the application of) (n 140) and Jedwell, $R$ (on the application of) $v$ Denbighshire County Council [2016] EWHC 458 (Admin) [16].

${ }^{143}$ Holder v Gedling Borough Council [2014] EWCA Civ 599.

${ }^{144}$ Community Power Ltd., $R$ (on the application of) v National Assembly for Wales [2004] EWHC 2186 (Admin) [24].

${ }^{145}$ Jones $v$ Mordue [2015] EWCA Civ 1243 [2].

${ }^{146}$ Sustainable Shetland (n 39) and Skye Windfram Action Group Limited: Re Judicial Review (n 106).

${ }^{147}$ Howell (n 28). 
Thus, for example, there are at least 24 cases $^{148}$ that raise grounds concerning how the building of a wind turbine interrelates with the legal duty under s 66(1) of the Planning (Listing Building and Conservation Areas) Act $1990^{149}$ which states that

In considering whether to grant planning permission for development which affects a listed building or its setting, the local planning authority or, as the case may be, the Secretary of State shall have special regard to the desirability of preserving the building or its setting or any features of special architectural or historic interest which it possesses. ${ }^{150}$

These cases are about what this duty means (in particular the concept of 'special regard') ${ }^{151}$, a duty that is often fleshed out in planning policy. ${ }^{152}$ The question of the 'setting' of a building is highly dependent on circumstances. ${ }^{153}$ Thus in these cases the duty in regards to wind energy

${ }^{148}$ A good recent overview of this case law can be found in Williams, $R$ (On the Application of) v Powys County Council [2017] EWCA Civ 427, [42]-[58].

149 or the Scottish equivalent, Planning (Listed Buildings and Conservation Areas) (Scotland) Act 1997.

150 Note it was amended in 2016 to include 'or permission in principle' after planning permission.

${ }^{151}$ Barnwell Manor Wind Energy Ltd.

${ }^{152}$ Williams, $R$ (On the Application of) (n 148) [45].

153 Ibid [56]. 
projects arises in relation to a wide array of listed buildings including a bricked-up folly, ${ }^{154}$ Dylan Thomas' writing shed, ${ }^{155}$ and a Roman Road. ${ }^{156}$

Most importantly, the reasoning closely clings to the section 66 legal framework. As noted in one case:

It seems to me that the clearest indication of whether there is an effect on something that is itself a creature of statute is to see whether the purpose for which statute created it is affected. The purpose of the creation of the notion of a monument and its site is preservation, not amenity; and it follows that action will 'affect the site of a scheduled monument' if it goes to its preservation but not if it affects only its amenity. ${ }^{157}$

Thus, the legal frame is dictating the nature of the legal inquiry. In relation to the case concerning Thomas' writing shed the Planning Officer had noted that 'the site of the proposal is clearly seen from Dylan Thomas' desk in the writing shed. The tranquil serenity of the mouth of the estuary is said to have inspired Dylan Thomas' work, and therefore the view is considered to be of international and cultural importance'. ${ }^{158}$

${ }^{154}$ North Cote Farms Ltd v Secretary of State for Communities and Local Government [2015] EWHC 292 (Admin).

${ }^{155}$ Davies, $R$ (On the Application of) v Carmarthenshire County Council [2015] EWHC 230 (Admin).

156 Wind Prospect Developments Ltd v Secretary of State for Communities And Local Government [2014] EWHC 404 (Admin) .

157 Williams, $R$ (on the application of) (n 110) [44].

158 As quoted in Davies, $R$ (On the Application of)(n 155) [3]. 
As is clear from this last quote, these legal obligations that relate to those protected places have been created at the national, EU or even at times at the international level. The axis of the cases, as it is with many planning cases is with reconciling different and conflicting legal commitments in a legal order created by legislation. Any particular judgment can be seen to play an important role in considering one of these processes of reconciliation. Thus, in one case, the judge noted that the case was an Aarhus claim and that 'the impact of the turbine on heritage asserts deserves an airing in court'. ${ }^{159}$

A similar situation can be seen with cases that raise issues about environmental impact assessment obligations ${ }^{160}$ and nature conservation obligations. ${ }^{161}$ For example, environmental impact assessment is required under an EU directive for projects 'likely to have significant effects on the environment'. ${ }^{162}$ The Directive is implemented through delegated legislation. ${ }^{163}$ Annex 2 of the Directive requires decision-makers to consider whether 'Installations for the

${ }^{159}$ Williams, $R$ (on the application of) (n 110) [4].

${ }^{160}$ Eg Gregory v Welsh Ministers [2013] EWHC 63 (Admin); Hargreaves v Secretary of State for Communities \& Local Government [2012] EWCA Civ 241; and The John Muir Trust, Re Judicial Review [2015] ScotCS CSOH_163.

161 Eg Sustainable Shetland (n 39); Hubert (n 112) [52]-[53]; and Corbett, $R$ (On the Application Of) v Cornwall Council [2013] EWHC 3958 (Admin) [79]-[83].

162 Directive 2014/52/EU of the European Parliament and of the Council of 16 April 2014 amending Directive 2011/92/EU on the assessment of the effects of certain public and private projects on the environment (as amended) [2014] OJ L124/1.

163 The most recent being The Town and Country Planning (Environmental Impact Assessment) Regulations 2017. 
harnessing of wind power for energy production (wind farms)' require an EIA. Making such a decision is known as a screening opinion.

In regards to wind energy projects, numerous questions have arisen in these cases including: what needs to be taken into account in a screening opinion; ${ }^{164}$ the process for making a screening opinion; ${ }^{165}$ the reasoning required for such an opinion; ${ }^{166}$ how accessible data should be to objectors; ${ }^{167}$ and what factors are 'material' for the reversing of such a determination. ${ }^{168}$

A similar pattern can be seen in relation to nature conservation, where the challenges before the court relate to how the building of a wind turbine will impact on what is protected by EU nature conservation law. For example, there are challenges to the reasoning involved in making that assessment ${ }^{169}$ and what information is required to make it. ${ }^{170}$ The most important thing is that the analysis of the judges in these cases focuses on the web of legal obligations that decision-makers are subject to. There is often uncertainty about the relationship between

${ }^{164}$ Hubert (n 112) [40]-[45].

${ }^{165}$ Gregory (n 160).

166 Jedwell v Denbighshire County Council [2015] EWCA Civ 1232.

${ }^{167}$ Finn-Kelcey v Milton Keynes Council [2008] EWCA Civ 1067, [30]

${ }^{168}$ Mageean, $R$ (on the application of) (n 140) [44].

${ }^{169}$ Bagmoore Wind Ltd v The Scottish Ministers [2012] ScotCS CSIH_93.

${ }^{170}$ Mynydd Y Gwynt Ltd, R (on the application of) $v$ The Secretary of State for Business Energy and Industrial Strategy [2016] EWHC 2581 (Admin) . 
different legislative obligations. As Lord Carnwath noted in Sustainable Shetland v Scottish Ministers,

...the principal difference between the courts below, .... lay in their respective assessments of the role of the ministers in considering a proposal of this kind. The Lord Ordinary treated it as requiring them in effect to conduct a full review of their functions under the Birds Directive, with a view to considering how the present proposal would contribute to or fit in with those functions, and in particular the objective of bringing the whimbrel up to "favourable conservation status". The Inner House took a more limited view. The directive was but one of a number of material considerations to be taken into account in reaching a lawful decision whether to grant consent under the Electricity Act $1989 .{ }^{171}$

Lord Carnwath favoured the latter view.

Overall, the role of parties in these cases is identifying the possible legal implications of the building of a wind turbine for other legal regimes. Not all these arguments succeed, and some are more fanciful than others, but the important point to note is the questions before the court are about how the building of a wind energy project raises questions about the nature of pre-existing legal obligations. An energy transition is not 'seamless'. ${ }^{172}$

Scanning this case law is a reminder of how planning law is not just framing wind energy projects, but also how law more generally 'frames' the natural environment and our

\footnotetext{
${ }^{171}$ Sustainable Shetland (n 39) [29].

172 Jasanoff and Kim, 'Socio-Technical Imaginaries and National Energy Policy’ (n 20).
} 
interactions with it. ${ }^{173}$ Different geographical spaces are given legal significance through legal designations and those designations affect what can be built on and around them. ${ }^{174}$ Building any wind energy project will need to be reconciled with these designations. Given how little attention is given to such reconciliation in renewable energy policy and how much it depends on specific facts, these grounds of challenge are not surprising. Thus, while the case law in relation to Listed Buildings may seem curious, it is also inevitable that a body of case law needs to develop to reconcile the 'special regard to the desirability of preserving the building or its setting ${ }^{175}$ with the a-typical nature of a wind turbine.

\subsection{Interpreting Wind Energy Planning Policy and Planning Conditions}

Legal uncertainties do not just exist in relation to how a wind energy project interacts with other legal regimes however. They also exist in relation to how to interpret planning policies and planning conditions that explicitly relate to wind turbine projects. Planning policy and planning conditions are not new to planning law. The role of planning policy was discussed above. All planning permissions are accompanied with planning conditions which play an important role in regulating what is built. ${ }^{176}$ Nor are legal challenges relating to the

173 Hilson, 'Framing Fracking: Which Frames Are Heard in English Planning and Environmental Policy and Practice?' (n 10) and Stokes, 'Regulatory Domain and Regulatory Dexterity' (n 66).

${ }^{174}$ On the importance of these designations see Fisher, Lange and Scotford, Environmental Law: Text, Cases and Materials (n 33) Ch 20.

${ }^{175}$ Section 66 Planning (Listed Building and conservation Areas) Act 1990.

${ }^{176}$ Duxbury, Telling \& Duxbury's Planinng Law and Procedure (n 60). 
interpretation of policy and conditions new. ${ }^{177}$ This is because while the important role of planning judgement is always recognised, the authoritative interpretation of planning policy is understood as the court's role. ${ }^{178}$ With that said, this becomes a live issue in regards to wind energy projects because new authoritative documentation has been created and is in need of interpretation.

Thus, the first reported legal challenge relating to a wind energy project was in 1995 by a developer challenging the refusal of their planning application. The issue in the case was how to interpret the then relevant policy guidance in regards to renewable energy, PPG 22. After considering the entire document the judge concluded that:

... looking at PPG 22 as a whole, it is seen that, while it gives great importance to the provision of energy from the renewable sources, it does not provide a presumption in favour of such development, nor does it preclude a proper balancing between that need for energy from renewable sources and those policies which protect the environment and other interests of acknowledged importance. In so far as there are factors which can reasonably be taken into account in weighing the need in any particular case then it is appropriate that such factors should be taken into account. ${ }^{179}$

PPG22 was replaced with PPS22 in 2004, and that also gave rise to legal questions about its interpretation and application. ${ }^{180}$ There have also been a number of cases raising issues to do

${ }^{177}$ Eg see Tesco Stores Ltd v Dundee City Council (Scotland) [2012] UKSC 13

${ }^{178}$ Ibid and Newark \& Sherwood District Council (n 120) [14].

${ }^{179}$ West Coast Wind Farms Limited v Secretary of State for the Environment [1996] Env LR $29,37$.

${ }^{180}$ Hulme, $R$ (on the application of) $v$ Secretary of State for Communities \& Local Government [2010] EWHC 2386 (Admin) [91]-[95] and North Devon District Council, $R$ (on the 
with the interpretation of the National Planning Policy Framework. ${ }^{181}$ The legal relevance of NPSs has also been the subject of litigation ${ }^{182}$ as have the legal significance of other germane planning documents and circulars. ${ }^{183}$ The interpretation of technical guidance relating to noise issues has also been in the subject of challenge. ${ }^{184}$

Legal challenges have also related to local policy as set out in local development plans. Thus, for example, in one case a court needed to determine whether a development fell under one local development plan paragraph or another and in doing so deciding whether it was a 'wind farm' or a 'small scale renewable energy project'. ${ }^{185}$ Other questions have arisen about which policy provisions apply, ${ }^{186}$ the legal relationship between different local planning

application of) $v$ Enterprise \& Regulatory Reform Secretary of State for Business [2008] EWHC 1700 (Admin) [40]-[50].

${ }^{181}$ Howell v Secretary of State for Communities And Local Government [2015] EWCA Civ 1189 [60-61], Colman v Secretary of State for Communities and Local Government [2013] EWHC 1138 and Martin (n 111) [3]

${ }^{182}$ Jones, $R$ (on the application of) $v$ The Secretary of State for Business Energy and Industrial Strategy [2017] EWHC 1111 (Admin) and Powys County Council (n 132) [35]-[57].

${ }^{183}$ Powys County Council (n 132) [62]-[67].

${ }^{184}$ See (n 136) for documentation. For an example Joicey, $R$ (on the Application of) (n 115) [60]-[67] and Barnes (n 139) [26]-[27].

${ }^{185}$ Lancashire, $R$ (on the application of)(n 120) [17].

186 ibid. 
documents, ${ }^{187}$ whether proper regard was had to policy in the decision-making process, ${ }^{188}$ and the relationship between policy and legislation, ${ }^{189}$

Distinct, but also raising issues of interpretation and application, are cases relating to planning conditions and in particular planning conditions that regulate noise. Some of these concern the question of whether a planning condition should have been imposed, ${ }^{190}$ but many concern the interpretation and validity of conditions. ${ }^{191}$ Thus for example one of the two issues before the Supreme Court in Trump International Golf Club Scotland Limited v Scottish Ministers, ${ }^{192}$ concerned whether one of the planning conditions attached to a consent to a wind farm was 'unenforceable and also so uncertain that it [was] irrational'. ${ }^{193}$ The Court concluded otherwise, and in doing so Lords Hodge, Mance, and Carnwath highlighted in their judgments that there were different possible approaches to interpreting conditions. ${ }^{194}$

All these cases relate to specific policies and conditions but what these cases make clear is the way in which this documentation can be ambiguous and does not exist in a vacuum. Law

187 RWE Npower Renewables Ltd, $R$ (on the application of)(n 108) [83].

${ }^{188}$ Corbett, $R$ (On the Application Of) (n 146) [46]-[49].

${ }^{189}$ Howell (n 181) [22-23].

${ }^{190}$ Newark \& Sherwood District Council (n 120) [73]-[77].

191 Hulme v Secretary of State for Communities and Local Government [2011] EWCA Civ 638; Barnes (n 139) [21] and Hubert (n 112) [33-35].

192 Trump International Golf Club Scotland Ltd (n 103).

193 Ibid [23].

${ }^{194}$ Ibid [23]-[39], [41-[44], [45]-[71]. 
and policy frame understandings of wind energy projects, but those frames are not always in themselves legally certain. Legal disputes thus inevitably arise and there is a need for authoritative interpretations.

\subsection{Developing a Framework for 'Reasoned' Decision-Making}

The final category is those challenges that relate to the exercise of discretion of planning decision-makers whether they be officers or committees in local planning authorities, planning inspectors, or the Secretary of State. In some cases, these challenges relate to the general grounds of judicial review including procedural fairness, ${ }^{195}$ legitimate expectations, ${ }^{196}$ error of fact, ${ }^{197}$ relevant and irrelevant considerations, ${ }^{198}$ and Wednesbury unreasonableness. ${ }^{199}$ In all these cases, a rich body of general administrative law doctrine exists and the issue is the relationship between the decision granting or denying planning permission and these more general grounds.

Other grounds of challenge relate to specific issues that a wind energy project raises for the planning regime and the legal doctrines that have developed around it. For example, tcourts

${ }^{195}$ Glenmorie Wind Farm Ltd, Re Judicial Review (n 141), [27] and Powys County Council (n 182) $[58]-[61]$.

${ }^{196}$ Mageean, $R$ (on the application of) (n 140) [48]; Joicey, $R$ (on the Application of) (n 115) [45]-[47] and Glenmorie Wind Farm Ltd, Re Judicial Review (n 141)

${ }^{197}$ Williams, $R$ (on the application of) (n 110) [54] and Ecotricity Next Generation Ltd (n 108) [40].

${ }^{198}$ Benacre Estates Company (n 112) [34] and Holder (n 143) [5]-[6].

${ }^{199}$ Lancashire, $R$ (on the application of) (n 120) [9]. 
have ruled that a Secretary of State does not need to perform a site view of where a project will be built to overrule a Planning Inspector, ${ }^{200}$ and that the Secretary of State doesn't need to defer to a Planning Inspector because they have performed a site visit. ${ }^{201}$ There are also cases concerned with whether particular issues were properly ventilated in planning documents. ${ }^{202}$ Likewise, there are grounds of challenge relating to what is a 'material consideration'. ${ }^{203}$ The issue of whether granting planning permission to a turbine could act as a precedent and that that fact could be a material consideration (it could) was thus raised in one case, ${ }^{204}$ as were issues to do with the size and efficiency of turbines and the ability of them to meet need. ${ }^{205}$ Likewise, whether a decision maker had enough information to make an assessment of visual impact has also been litigated. ${ }^{206}$

What is particularly striking is how many of these cases concern whether the form of the formal reasons for granting or denying planning permission were legally acceptable. The starting point for this is the planning law doctrine that planning decisions must be adequately

${ }^{200}$ Ecotricity (Next Generation) Ltd $v$ Secretary of State for Communities \& Local Government (n 108) [38] and Johnston v HM Advocate [2016] ScotCS CSIH_20.

${ }^{201}$ Wind Prospect Developments Ltd (n 156) [26].

${ }^{202}$ The Friends of Hethel Ltd, $R$ (on the application of)(n 113) [62].

${ }^{203}$ Corbett, $R$ (On the Application Of) (n 161) [23]-[40].

${ }^{204}$ Holder (n 143) [15].

205 Ibid [24].

${ }^{206}$ Ecotricity (Next Generation) Ltd v Secretary of State for Communities \& Local Government (n 108) [35]. 
reasoned. As Lord Brown noted about the planning law doctrine concerning the giving of reasons:

The reasons for a decision must be intelligible and they must be adequate. They must enable the reader to understand why the matter was decided as it was and what conclusions were reached on the "principal important controversial issues", disclosing how any issue of law or fact was resolved. Reasons can be briefly stated, the degree of particularity required depending entirely on the nature of the issues falling for decision. The reasoning must not give rise to a substantial doubt as to whether the decisionmaker erred in law, for example by misunderstanding some relevant policy or some other important matter or by failing to reach a rational decision on relevant grounds. But such adverse inference will not readily be drawn. The reasons need refer only to the main issues in the dispute, not to every material consideration. They should enable disappointed developers to assess their prospects of obtaining some alternative development permission, or, as the case may be, their unsuccessful opponents to understand how the policy or approach underlying the grant of permission may impact upon future such applications. Decision letters must be read in a straightforward manner, recognising that they are addressed to parties well aware of the issues involved and the arguments advanced. ${ }^{207}$

I cite this at length because it is both a statement of a legal standard and also of a standard of rationality that relates to what decision-makers must show, what they must address, and how their reasons should be understood. In wind turbine cases issues about reasons arise in a variety of different contexts and include issues to do with the creation of reasons (for example a lack of proper contemporaneous notes $)^{208}$ and also how a court should review reasons. Thus, it is

${ }^{207}$ South Bucks District Council v Porter (No. 2) [2004] UKHL 33 [36]

${ }^{208}$ Jedwell, $R$ (on the application of) (n 142) [28], [84]. 
stressed there should not be a focusing on 'the minutae' ${ }^{209}$ and that reasons should be read as a whole. ${ }^{210}$

The requirement for reasons also overlaps with, and reinforces the legal obligations seen in Section 4.2 for example in relation to Listed Buildings ${ }^{211}$ or EIA screening. ${ }^{212}$ It also interrelates with grounds relating to policy in Section 4.3, and in particular whether policy was properly considered. ${ }^{213}$ There have been challenges about whether the reasons reveal whether legislative regimes were taken into account. ${ }^{214}$

This case law serves as a blueprint for what is understood as an acceptable course of action in relation to a wind energy project. Whether a court upholds a ground of challenge and what they say when they do shapes and frames understandings of what is good decisionmaking. What emerges from the case law is a commitment to the 'pragmatic nature of planning law'215 in which in developing yardsticks for acceptable decision-making there is a

${ }^{209}$ Newark \& Sherwood District Council (n 120) [10].

${ }^{210}$ Ecotricity Next Generation Ltd (n 130) [31].

211 Jones (n 145) [19] ; Jedwell (n 166) [50]; and East Northamptonshire District Council v Secretary of State for Communities and Local Government [2013] EWHC 473 (Admin) [67].

${ }^{212}$ Davies, $R$ (On the Application of) (n 155) [20].

${ }^{213}$ Benacre Estates Company (n 112) [34].

${ }^{214}$ Sustainable Shetland (n 39).

${ }^{215}$ Howell (n 28) [61]. 
commitment to ensuring decision-making is a matter of planning judgement ${ }^{216}$ and that any standards that the court imposes do not become a 'procedural nightmare'. ${ }^{217}$ As noted in one case an Inspector was not 'restrained by some kind of rigid analytical' process ${ }^{218}$ and planning judgement is informed by both 'experience and expertise'. ${ }^{219}$ Moreover, there is room for legitimate disagreement. Thus, the fact that decision makers come to different conclusions is not seen as necessarily problematic. ${ }^{220}$

\section{Energy Transitions and Planning Law Revisited}

Cranston $\mathrm{J}$ noted in a case in 2014 that the case was 'yet another challenge to a planning permission to erect a wind turbine'. ${ }^{221}$ The temptation is to see these challenges as getting in the way of a desired energy transition. Indeed, much of the policy and literature on energy transitions exhibits an impatience - either with the failure to move forward with an energy

${ }^{216}$ Wind Prospect Developments Ltd (n 156) [25] discussing the subjective and objective features of planning judgement.

${ }^{217}$ Ecotricity (Next Generation) Ltd $v$ Secretary of State for Communities \& Local Government (n 108) [44].

${ }^{218}$ Tegni Cymru Cyfv The Welsh Ministers [2010] EWHC 1106 (Admin) [45].

${ }^{219}$ Ibid [48].

${ }^{220}$ Wind Prospect Developments Ltd (n 156) [24] discussing how a Planning Inspector's report is a 'starting point for the Secretary of State's deliberation'. See also Tegni Cymru Cyf (n 118).

${ }^{221}$ Howell (n 28) [1]. 
transition $^{222}$ or with the failure of those promoting an energy transition to see its adverse impacts. ${ }^{223}$

The analysis above provides a different picture. Law is playing a substantive role in both framing wind energy developments and more significantly, in dealing with the inevitable legal disputes that arise. By substantive I mean that law and legal reasoning are constructing understandings of acceptable wind energy projects and how legitimate decisions are made in relation to them. In doing so, they are integrating these projects and decisions into the legal order and relating them to existing legal frameworks and settled understandings of good decision-making practices. ${ }^{224}$ An energy transition such as is involved in the shift to wind energy does not take place in a 'weightless, dematerialised' world. ${ }^{225}$ It is embedded in complex legal arrangements which need to be adjusted in light of infrastructural change. As Latour has noted, 'law has a homeostatic quality which is produced by the obligation to keep the fragile tissue of rules and texts intact'. ${ }^{226}$ Any change thus needs to be taken with care. The focus is on stability. As Latour notes 'All those aspects of law that common sense finds so

${ }^{222}$ McLaren Loring, 'Wind Energy Planning in England, Wales and Denmark: Factors Influencing Project Success' (n 8). A milder example can be seen in Neil Gunningham and Megan Bowman, 'Energy Regulation for a Low Carbon Economy: Obstacles and Opportunities'(2016) 33 Environmental Planning and Law Journal 118.

${ }^{223}$ Fiona Reynolds, The Fight For Beauty (Oneworld 2016) 221-4.

${ }^{224}$ Fisher, 'Environmental Law as "Hot" Law' (n 14).

${ }^{225}$ David Edgerton, The Shock of the Old: Technology and Global History Since 1900 (Profile Books 2006) 212.

${ }^{226}$ Latour, The Making of Law: An Ethnography of the Conseil D'etat (n 32) 242-3. 
irritating - its tardiness, its taste for tradition, its occasionally reactionary attitudes - are essential to law's functioning', ${ }^{227}$ This is because the focus in adjudication is on reconciling the novel with the existing legal order. This is not to say change does not occur, but change should be carefully reasoned. ${ }^{228}$

The reasoning in the case law above is inherently intricate. Law and legal reasoning evolve to frame understandings of: the legal significance of wind turbines; how decisionmaking about them is accommodated into the existing legal order; and what is 'reasonable' decision-making in relation to them. The frameworks and decisions discussed in Sections 3 and 4 are levelling the law, and making it 'even' in light of the disruption created by an energy transition. Energy transitions cause legal disruption, but the processes seen above - legislative reform and judicial review cases - are a means of incorporating such disruption into the legal order - a process of incorporation that can also involve reconfiguration of that order.

These legal processes thus create new standards and frames for decision-making through this process of reconciliation. In part this is through legislation and in part through the courts handing down authoritative judgments as part of the pragmatic common law tradition. ${ }^{229}$ In particular, it can be seen how these cases directly concern the practice of planning. ${ }^{230}$ In these decisions, courts are playing dual roles - resolving genuine legal disputes and also delivering a form of expository justice in which they are giving further substance to the legal

${ }^{227}$ Ibid

${ }^{228}$ Fisher, 'Environmental Law as "Hot" Law' (n 14).

${ }^{229}$ Booth, Planning By Consent (n 34) 4.

${ }^{230}$ Philip Booth, 'The Control of Discretion: Planing Law and the Common Law Tradtiion '(2007) 6 Planning Theory 127 
frameworks already created. ${ }^{231}$ While judicial review doctrine is not concerned with the merits it does generate a set of 'yardsticks' by which to judge the legal legitimacy and reasonableness of decisions. ${ }^{232}$ In judicial review challenges, courts are providing authoritative interpretations of legal and other frameworks and providing guidance for how discretion can and should be exercised so as to ensure that no error of law is committed. The legal focus is on the process of decision-making and the rationality of decision-making. Judicial review decisions thus serve as a blueprint for acceptable decisions. This is particularly when legal orders are expected to be stable and coherent. ${ }^{233}$ In part this is an aspiration to legal and regulatory certainty. ${ }^{234} \mathrm{In}$ part however, this reflects the need to address the disruption inherent in energy transitions.

All of the above is consistent with recent work in the social sciences that highlights the need to study the social work that goes into constructing infrastructures. ${ }^{235}$ What is obvious

${ }^{231}$ As discussed in Fisher, Scotford and Barritt, 'The Legally Disruptive Nature of Climate Change' (n 17).

${ }^{232}$ Elizabeth Fisher, Pasky Pascual and Wendy Wagner, 'Rethinking Judicial Review of Expert Agencies'(2015) 93 Texas Law Review 1681.

${ }^{233}$ There are many examples of these values being expressed but an excellent summary of the importance of legal stability can be found in Tom Bingham, The Rule of Law (Penguin 2010) $37-40$.

${ }^{234}$ Soren Krohn, Poul-Erik Morthorst and Shimon Awerbuch (eds), The Economics of Wind Energy (European Wind Energy Association 2009) 44-5, 75.

235 Penny Harvey, Casper Bruun Jensen and Atsuro Morita, 'Introduction: Infrastructural Complications' in Penny Harvey, Casper Bruun Jensen and Atsuro Morita (eds), Infrastructures and Social Complexity: A Companion (Routledge 2016) 20. 
from above, is that law is also playing an essential role. It is not only catalyzing an energy transition, but also framing it and dealing with the wider consequences of it. Laws are being co-produced with how we understand and live in the world. ${ }^{236}$ In doing so, law is adapting and evolving. ${ }^{237}$

The role of planning law in managing change was recognised by McAuslan in the 1970 s. ${ }^{238}$ It is also a theme in the case law and judges recognise the importance of bringing clarity and certainty to the decision-making process whether through proper policy guidance ${ }^{239}$ or through reasons that are clear and understandable. ${ }^{240}$ The problem has been, as seen in Section 2, that in areas of law such as planning law the focus has primarily been on the interests and ideologies protected by various legal regimes rather than on how law creates frames for action and creates forums for dispute resolution. From this perspective, planning law appears a legal quagmire that is understood to have little resonance in the real world. ${ }^{241}$ In the green light administrative law theory tradition courts are seen as hindrances to 'political progress'. ${ }^{242}$

${ }^{236}$ Elizabeth Fisher, Risk Regulation and Administrative Constitutionalism (Hart Publishing 2007).

${ }^{237}$ Fisher, 'Environmental Law as "Hot" Law' (n 14).

${ }^{238}$ JPWB McAuslan, 'The Plan, The Planners, and the Lawyers'(1971) Public Law 247, 274.

${ }^{239}$ Glenmorie Wind Farm Ltd, Re Judicial Review (n 141) [36];

${ }^{240}$ Welsh Ministers v RWE NPower Renewables Ltd [2012] EWCA Civ 311 [40].

${ }^{241}$ McAuslan, 'Planning Law's Contribution to the Problems of an Urban Society' (n 56).

242 Harlow and Rawlings, Law and Administration (n 53) 31. Also see McAuslan, ‘Administrative Law, Collective Consumption and Judicial Policy' (n 55). 
While McAuslan saw the possibility of shifting the ideological emphasis of planning law, ${ }^{243}$ he ultimately, as Loughlin notes, saw 'law [as] merely an instrument for achieving particular objectives; legal decisions are thus to be evaluated in terms of outcomes; and those who make such decisions must be held to account for their politics and their prejudices'.244 McAuslan in his writings was correct to critique an 'objective' account of the law. ${ }^{245}$ Areas such as planning law are balancing a range of different aspirations and interests. This can be seen in legislation, in policy and in case law. But as the analysis in Section 3 and 4 shows it is not just a site for the compromise between these different interests. Rather it is a framework that regulates and in doing so incorporates regulatory objects and the practices around them into the legal order. By focusing on ideology, there is a real danger that scholars overlook the complexity of law and what it is doing. That is not only in relation energy transitions, but in regards to other areas of social regulation and administrative law where instrumental understandings of law have tended to dominate. ${ }^{246}$ To be blunt there is a need for scholars in the context of both energy transitions and planning law to take law more seriously. In regards to the former, there is a need to understand the many different ways in which a new technology - the mass use of wind energy - is accommodated into the legal order. In regards to the latter,

${ }^{243}$ McAuslan, The Ideologies of Planning Law (n 12).

${ }^{244}$ Loughlin, Public Law And Political Theory (n 54) 205-6.

${ }^{245}$ McAuslan, The Ideologies of Planning Law (n 12) 4.

${ }^{246}$ Environmental law is a prime example. For substantive critiques of instrumental approaches see Sanja Bogojevic, Emissions Trading Schemes: Markets, States and Law (Hart 2013) and Eloise Scotford, Environmental Principles and the Evolution of Environmental Law (Bloomsbury 2017). 
there is a need to understand the ways in which planning law frames such a technology and the practices around it.

\section{Conclusion}

David Feldman has argued that 'scholarship involves curiosity about the world'. ${ }^{247}$ As such, scholarship must be guided by 'a commitment to employing methods of investigation and analysis best suited to satisfying that curiosity'. ${ }^{248}$ This article started out by me wanting to satisfy my curiosity about what legal challenges to wind turbine decision-making were really about. Given how wind energy has been portrayed in policy and social science literature there is a common assumption that these cases pivot around the global versus the local, ${ }^{249}$ or involve a clash of interests. Few people expect them to be about Listed Buildings or interpreting planning conditions or what type of reasons a planning inspector should provide.

But that says much about the limits of the scholarly lens we use to view energy transitions and planning law. Not only is it striking that there has been little in the way of scholarship that has charted the case law in this area, but given the ways in which an energy future 'reconfigure[s] the physical deep structures of civilizations' ${ }^{250}$ it is also surprising that people find the substance of these cases surprising. It is inevitable that the building of a wind turbine will give rise to these types of issues.

${ }^{247}$ David Feldman, 'The Nature of Legal Scholarship'(1989) 52 Modern Law Review 498, 502.

248 Ibid 503.

${ }^{249}$ (n 8).

250 Jasanoff and Kim, ‘Socio-Technical Imaginaries and National Energy Policy’ (n 20). 
Overall, what can be seen is the way in which law is not only framing understandings of wind energy and how decisions should be made in relation to it but also providing forums for dispute resolution which in turn through the development of legal doctrine thicken understandings of good decision-making in this area. Whatever else law may be, law is not just an instrument for particular ends. 